\title{
Investment, growth, and defense expenditure in the EU15: Revisiting the nexus using SIPRI's new consistent dataset
}

\section{Christos Kollias and Suzanna-Maria Paleologou}

Christos Kollias is Professor of Economics at the Department of Economics, University of Thessaly, Greece. The corresponding author, he can be reached at kollias@uth.gr. Suzanna-Maria Paleologou is Associate Professor of Economics at the Department of Economics, Aristotle University of Thessaloniki, Greece. She can be reached at smp@econ.auth.gr.

\section{Abstract}

Using SIPRI's new consistent database on military expenditure and employing a panel vector autoregression (PVAR) methodology, the article investigates the nexus between military expenditure and two key macroeconomic variables, namely growth rates and investment spending for the case of the EU15 countries over the period 1961-2014. The findings reported herein do not support the effective demand stimulation argument for military spending. Thus, they broadly confirm the results of earlier studies for the EU15 that used the previous version of the SIPRI dataset.

$\mathrm{T}$ he economic ramifications of military spending is the theme of an impressively large and steadily growing body of empirical studies. Since comprehensive surveys of the literature can be found in Dunne and Uye and Dunne and Tian, we refrain from producing a literature review here. Broadly speaking, though, the discussion regarding the economic effects of military expenditure may be grouped into several categories. An obvious starting point regards the opportunity cost of the resources allocated to defense. This is especially relevant for the case of developing countries that face both, more acute resource constraints when compared to developed ones and pressing developmental challenges such as much needed public sector spending on health or education that could potentially be partially met by the resources allocated to defense uses. Apart from this guns versus butter issue, demand and supply-side effects are associated with military expenditure and the multiple channels through which it can affect an economy. Demand-side channels refer to stimulative effects of increased employment of otherwise idle or underemployed resources with the concomitant propping-up of economic activity and growth, whereas supply-side aspects point to positive externalities such as technological advances that spill over to other sectors of the economy thus increasing productivity, infrastructure creation, and human capital formation. The supply-side view is not unchallenged and critics argue with fervor that nonmilitary forms of government spending, for instance infrastructure expenditure, may very well have an equal if not greater positive impact on the economy. Furthermore, by possibly crowding out more productive forms of public expenditure as well as private sector investment, military expenditure can retard growth. In broad terms, the literature has not produced robust empirical consistency in the reported findings. ${ }^{1}$

The Stockholm International Peace Research Institute (SIPRI) recently revised and extended its military expenditure database. It now offers consistent estimates across countries for an appreciably longer time period - as from the early 1950s rather than as from 1988 onward - that spans both the cold war and post-cold war periods. This presents the opportunity to (re)assess the subject matter of the economic effects of military expenditure using consistent time series over a significantly longer time horizon in a statistically more robust way and leading to more reliable inferences than before. Using this new consistent database, this article addresses the issue at hand for the case of the EU15 group of countries and contributes to the literature through the extension of the time period examined. To this effect, we concentrate onto two key macroeconomic variables - economic growth and gross domestic investmentthat have repeatedly featured in empirical studies that assess the economic impact of military spending. The next section of this article contains a brief descriptive and comparative presentation of the variables used in the empirical analysis. The methodology employed to probe the research question at hand is outlined in the section thereafter, and the results are presented and discussed. The final section concludes. ${ }^{2}$

\section{The variables}

As noted, the macroeconomic variables used in the empirical investigation are the defense burden (i.e., military expenditure as a share of GDP), the annual growth rate of GDP, and investment as a share of GDP. For each of the EU15, Table 1 shows the average, maximum, and minimum values for these 
Table 1: Descriptive statistics, 1961-2014 (in percent)

\begin{tabular}{|c|c|c|c|c|c|c|c|c|c|}
\hline & Average & Max. & Min. & Average & Max. & Min. & Average & Max. & Min. \\
\hline & $\underline{\text { Belgium }}$ & & & $\underline{\text { Spain }}$ & & & $\underline{\text { Austria }}$ & & \\
\hline Growth & 2.7 & 7.0 & -2.3 & 3.5 & 11.8 & -3.6 & 2.8 & 6.3 & -3.8 \\
\hline Inv/GDP & 23.2 & 27.3 & 18.5 & 24.3 & 31.1 & 19.2 & 25.8 & 32.0 & 21.6 \\
\hline \multirow[t]{2}{*}{ Milex/GDP } & 2.3 & 3.4 & 1.0 & 2.0 & 3.0 & 1.2 & 1.2 & 1.9 & 0.8 \\
\hline & Denmark & & & $\underline{\text { France }}$ & & & $\underline{\text { Portugal }}$ & & \\
\hline Growth & 2.3 & 9.3 & -5.1 & 2.8 & 7.0 & -2.9 & 3.3 & 12.6 & -4.3 \\
\hline Inv/GDP & 21.6 & 25.8 & 17.2 & 23.0 & 26.8 & 19.4 & 25.3 & 33.4 & 14.8 \\
\hline \multirow[t]{2}{*}{ Milex/GDP } & 2.0 & 3.0 & 1.3 & 3.6 & 6.5 & 2.2 & 3.1 & 6.0 & 1.9 \\
\hline & Germany & & & $\underline{\text { Italy }}$ & & & $\underline{\text { Finland }}$ & & \\
\hline Growth & 2.5 & 7.5 & -5.6 & 2.5 & 8.2 & -5.5 & 2.9 & 9.6 & -8.3 \\
\hline Inv/GDP & 22.1 & 26.6 & 19.1 & 22.4 & 28.3 & 16.6 & 25.3 & 33.0 & 18.6 \\
\hline \multirow[t]{2}{*}{ Milex/GDP } & 2.6 & 5.2 & 1.2 & 2.2 & 3.4 & 1.5 & 1.6 & 2.5 & 1.2 \\
\hline & Ireland & & & Luxembourg & & & $\underline{\text { Sweden }}$ & & \\
\hline Growth & 4.4 & 11.2 & -5.6 & 3.7 & 10.0 & -6.6 & 2.5 & 6.8 & -5.2 \\
\hline Inv/GDP & 22.1 & 31.0 & 14.9 & 20.4 & 27.5 & 14.4 & 23.9 & 29.1 & 19.2 \\
\hline \multirow[t]{2}{*}{ Milex/GDP } & 1.2 & 1.9 & 0.5 & 0.9 & 1.4 & 0.5 & 2.6 & 4.0 & 1.2 \\
\hline & Greece & & & Netherlands & & & U.K. & & \\
\hline Growth & 2.9 & 11.1 & -9.1 & 2.9 & 8.6 & -3.8 & 2.4 & 6.5 & -4.2 \\
\hline Inv/GDP & 24.0 & 35.4 & 11.6 & 23.3 & 29.4 & 17.9 & 20.2 & 26.5 & 16.0 \\
\hline Milex/GDP & 3.9 & 5.9 & 2.2 & 2.6 & 4.6 & 1.2 & 4.0 & 6.3 & 2.2 \\
\hline
\end{tabular}

Note: Growth (annual percentage change in GDP); Inv/GDP (investment ratio); Milex/GDP (military burden). Source: SIPRI.

variable for 1961-2014. Starting with the defense burden, the EU15 present a varied picture. Countries such as the United Kingdom, France, and Greece have on average allocated a relatively high proportion of their national income to defense: 4.0,3.6, and 3.9 percent, respectively. Others show appreciably lower numbers: Ireland and Austria for example average 1.2, Finland 1.6, and Luxembourg only 0.9 percent. Compared to the EU15's average of 2.4 percent, the bottom panel in Figure 1 (next page) shows that in addition to France, Greece, and the U.K., Germany, the Netherlands, Portugal, and Sweden, also have on average allocated an above-average percentage of their GDP to defense. As Eftychia Nikolaidou has pointed out, there is little uniformity in the domestic and external factors that determine each country's allocation of resources to defense. A cohort of economic, political, strategic, and security factors have shaped the demand for military expenditure in each of the EU15 which explains the notable differences in their defense burdens. $^{3}$

A similar diversity among the EU15 is observed with respect to the other two variables (Table 1 and Figure 1, top and middle panels). Compared to the group's average growth rate of 2.9 percent, clear over- and underperformers emerge (see the top panel in Figure 1). Ireland (with an average growth rate of 4.4 percent) is followed by Luxembourg (3.7), Spain (3.5), and Portugal (3.3). Others, for instance Denmark (2.3), the United Kingdom (2.4), and Germany (2.5) underperformed relative to the group's average. A similarly diverse picture holds with respect to the third variable. The group's average investment expenditure as a share of GDP was 23.1 percent. The biggest over-performers Austria (25.8 percent), followed by Portugal and Finland (25.3 percent each). The three main underperformers are the United Kingdom (20.2), Luxembourg (20.4), and Denmark (21.6).

\section{Methods and results}

To investigate the effect of military expenditure on investment and growth for the EU15, a balanced panel of time series data was constructed for the period 1961-2014. We estimate models of the form given in equations (1), (2), and (3) and the panel vector autoregression (PVAR) given in equation (7) where inv is investments as a share of GDP, milex is military spending expressed as a share of GDP and $g d p$ is the economy-wide growth rate. For the same time period, we also estimate a panel of data for six countries deemed to posses a significant defense industrial base: France, Germany, Italy, Spain, Sweden, and the U.K. The effective demand stimulation argument postulates 
that higher military spending can bring about increased utilization of idle or underemployed capital stock, induce investment and hence, through short-run multiplier effects, prop-up growth rates. Since such an effect would probably be more evident in countries that have a developed defense industrial base able to produce manufacturing inputs for the defense sector, our choice here is to estimate a subsample with the six mentioned countries. ${ }^{4}$

\section{Pooled OLS}

(1) $i n v_{j t}=\alpha+\beta m i l e x+\gamma g d p_{j t}+\epsilon_{j t}$

Fixed Effects Panel Estimator (FE)

(2) $i n v_{j t}=\alpha_{j}+\beta$ milex $_{j t}+\gamma g d p_{j t}+\epsilon_{j t}$

Random Coefficient Estimator (RCE)

(3) $i n v_{j t}=\alpha_{j}+\beta_{j}$ milex $_{j t}+\gamma_{j} g d p_{j t}+\epsilon_{j t}$

and calculates weighted averages of the individual time series estimates $\hat{\beta}_{j}$ and $\hat{\gamma}_{j}$, namely $\widetilde{\beta}_{R}=\sum_{j} w_{j} \hat{\beta}_{j}$ and $\widetilde{\gamma}_{R}=\sum_{j} w_{j} \hat{\gamma}_{j}$.

To specify whether a fixed or a random effects model is more appropriate to use, we performed the Hausman test, distributed as a $\chi^{2}(2)$. In our case, this yield values of 40.17 for the EU15 sample and 40.03 for the EU6 and indicate that the random effects model is rejected at the 5 and 1 percent levels, respectively. This finding is consistent with the literature since random effects models are considered more appropriate than fixed effect models only when the results are used to make an inference from a sample to a population, which is not our case. Instead, we are interested in estimating the group and time effects that may exist within our sample. Parameter estimates for the Pooled OLS, FE, and RCE models are shown in Table 2. The results obtained for the EU15 show a significant positive effect of the economy's growth rate and the share of military expenditure in GDP on the share of investment in GDP only in the case of the FE and RCE methods. In the case of the EU6, the same positive effect is obtained only with the FE estimation. $^{5}$

As noted, to further explore the relation between military expenditure and the economy, we employ a panel VAR, or PVAR, which extends Sim's traditional vector autoregression (VAR) with a panel data approach. An analysis based on VAR offers several advantages. Although, strictly speaking, atheoretical, it is a flexible method that treats all variables in the system as endogenous and independent, without worrying about the direction of causality. Each variable is explained by its own lags and by lagged values of the other variables. It is a system of equations rather than a one-equation model. Panel

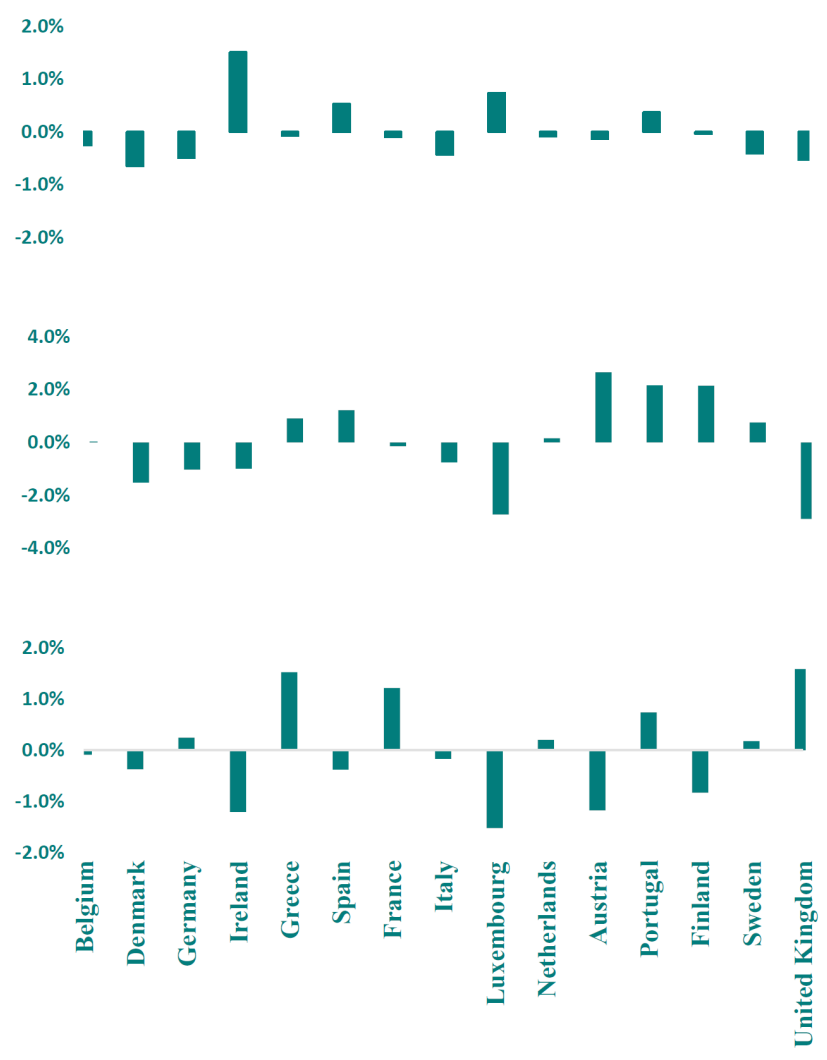

Figure 1: Over- and underperformance of EU15 relative to sample averages. Top: Growth rates. Middle: Investment to GDP ratio. Bottom: Military expenditure to GDP ratio. Source: SIPRI and authors' calculations.

VAR allows for unobserved individual heterogeneity, improves asymptotic results, and simplifies the choice of suitable instrumental variables. The general form of a PVAR model is exemplified by Canova and Ciccarelli (2004): ${ }^{6}$

(4) $y_{i t}=A_{0} a_{i t}+L_{1} y_{i t-1}+\ldots+L_{p} y_{i, t-p}+u_{t}$,

where $y_{i t}$ is a $K \times 1$ vector of a $K$ panel data of variables; $i=1$, $\ldots, I, a_{i t}$ is a vector of deterministic terms such as linear trend, dummy variables, or a constant; $A_{0}$ is the associated parameter matrix; and the $L$ 's are $K \times K$ parameter matrices attached to the lagged variables $\mathrm{y}_{\mathrm{i}, \mathrm{t}-\mathrm{p}}$. The lag order (VAR order) is denoted by $p$. The error process, $\mathrm{u}_{\mathrm{t}}$, consists of three components:

(5) $u_{t}=\mu_{i}+\gamma_{t}+\epsilon_{i t}$,

with $\mu_{i}$ representing the country-specific effect, $\gamma_{t}$ capturing the time effect, and $\epsilon_{i t}$ is the disturbance term. The error term $u_{t}$ is assumed to have zero mean, $E\left(u_{t}\right)=0$, and the time invariant covariance matrix and $u_{t} s$ are independent. This specification 


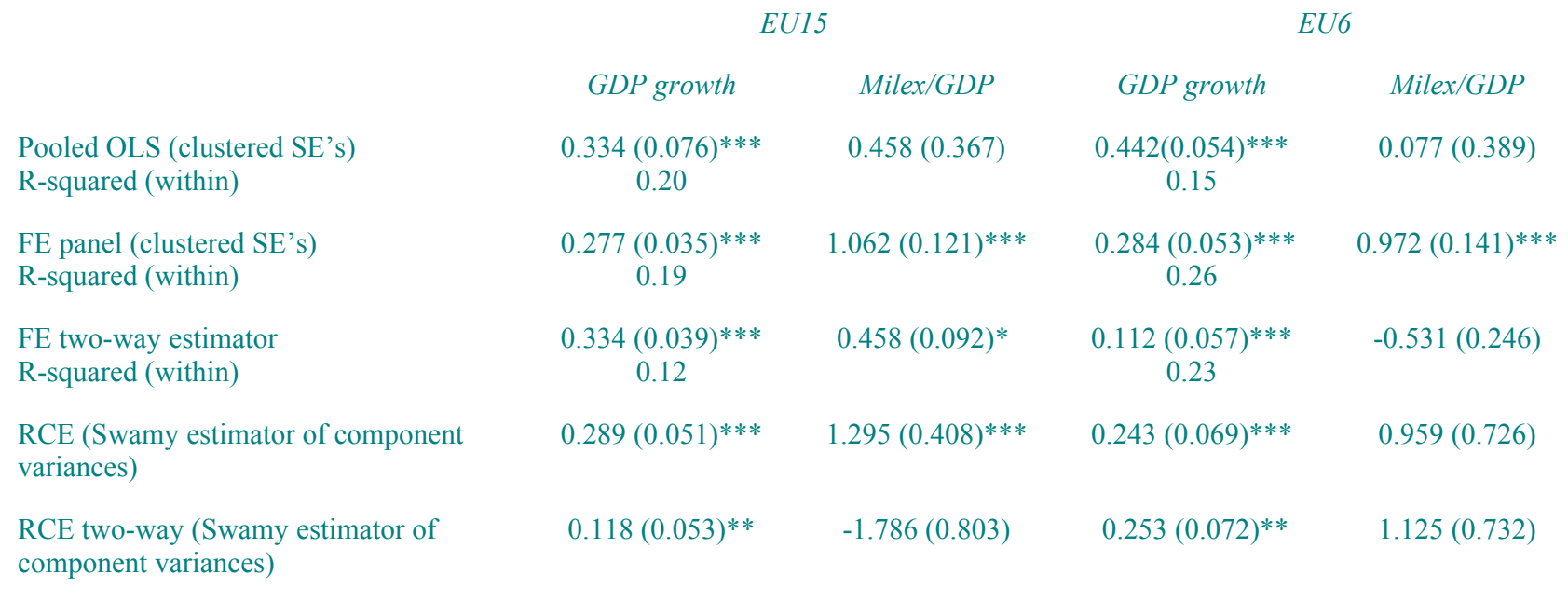

Notes: With the RCE the random effects contribute only to the covariance and therefore there are no random effects sum of squares to calculate the R-squared correlation coefficient. *** statistically significant at the $1 \%$ level; S.E in parenthesis.

imposes two restrictions: It assumes common slope coefficients and it does not allow for interdependencies across units. Given these restrictions, the estimated matrices $L$ are interpreted as average dynamics in response to shocks. As with standard VAR models, all variables depend on the past of all variables in the system, the main difference being the presence of the individual country-specific terms $\mu_{i}$.

The PVAR approach is used to estimate the relation among GDP growth rates, investment, and military expenditure. In line with prior literature, the latter two are both expressed as shares of GDP. VAR modeling does not require the imposition of strong structural relationships, although theory is involved to select the appropriate normalization and to interpret the results. Another advantage is that only a minimal set of assumptions is needed to interpret the impact of shocks on each variable in the PVAR system. The reduced form VAR, once the unknown parameters are estimated, permits implementing dynamic simulations. This method only allows for the analysis of short-run adjustment effects and not of structural long-run effects. The results come in the form of impulse response functions (IRFs), and their coefficients analysis, as well as forecast error variance decompositions (FEVDs) that permit one to examine the impact of innovations or shocks to any particular variable on other variables in the system. IRFs model the dynamics of the response, the coefficients represent the average effects of IRFs and permit recognizing the significance of the overall response, while variance decompositions give information about the variation in one variable due to a shock to the others. The response corresponds to a one-time shock in other variables, holding all the other shocks constant at zero. In other words, orthogonalizing the response allows one to identify the effect of one shock at a time, while holding other shocks constant. We are particularly interested in the response of investment due to shocks in GDP growth rates and military expenditure. $^{7}$

To obtain orthogonalized impulse response functions, we decompose the residuals in a way that makes them orthogonal. Such exercises require applying a careful VAR identification procedure. The most common way to deal with this problem is to choose a causal ordering. We adopt the Choleski decomposition of variance-covariance matrix of residuals. This process is called VAR identification and involves a particular ordering of variables in the VAR system. We allocate any correlation between the residuals to the variable that appears earlier in the ordering. The identifying assumption is that the variables that appear earlier in the system are more exogenous, and those which appear later are more endogenous. This implies that variables that appear earlier affect the following variables contemporaneously and with lags, while the variables that appear later only affect the previous variables with lag. We treat the share of military expenditure in GDP as the most exogenous variable and the share of investment in GDP as the most endogenous one. GDP growth rates are used as a buffer variable. $^{8}$

(6) milex/GDP $\rightarrow$ GDP growth rate $\rightarrow$ investment/GDP.

As a set of endogenous equations, all variables influence 
each other. The simplest three-variable PVAR model is specified and can be represented as equation (7)

$$
\begin{aligned}
& {\left[\begin{array}{ccc}
1 & a_{12} & a_{13} \\
a_{21} & 1 & a_{23} \\
a_{31} & a_{32} & 1
\end{array}\right]\left[\begin{array}{c}
\Delta \frac{\text { milex }}{\text { gdp }}_{i t} \\
\Delta g d p_{i t} \\
\Delta \frac{\text { inv }}{\text { gdp }}_{i t}
\end{array}\right]=} \\
& {\left[\begin{array}{l}
a_{10} \\
a_{20} \\
a_{30}
\end{array}\right]+\left[\begin{array}{lll}
L_{11} & L_{12} & L_{13} \\
L_{21} & L_{22} & L_{23} \\
L_{31} & L_{32} & L_{33}
\end{array}\right]\left[\begin{array}{c}
\Delta \frac{\text { milex }}{g d p}_{i, t-p} \\
\Delta g d p_{i, t-p} \\
\Delta \frac{i n v}{g d p}_{i, t-p}
\end{array}\right]+\left[\begin{array}{l}
u_{1} \\
u_{2} \\
u_{3}
\end{array}\right]}
\end{aligned}
$$

where $y_{i t}$ on the left-hand side of the equation is a three-variable vector including 3 endogenous variables: The share of military expenditure in GDP, GDP growth rates, and the share of investment in GDP. On the right-hand side, the $3 \times 3$ matrix $L$ contains the coefficients of contemporaneous relationships among these three variables. As noted, we are interested in the impulse responses of the share of investment in GDP to shocks in the share of military expenditure in GDP and to shocks in GDP growth rates.

Applying the VAR technique requires some data transformations to remove trends and only keep variations. The use of panel data imposes that the underlying structure is the same for each cross-sectional unit, i.e., that the coefficients in the matrices $L$ are the same for all countries in our sample. This constraint is violated in practice. To overcome this restriction and allow for country heterogeneity, fixed effects $\left(\mu_{i}\right)$ are introduced. However, fixed effects are correlated with the regressors due to lags of the dependent variables. We employ forward mean-differencing to eliminate the fixed effects. Also called a Helmert transformation, this procedure keeps the orthogonality between variables and their lags, so we can use the lags as instruments. ${ }^{9}$

Another issue is that of the cross-section autocorrelation being related to the common factors because panels with groups of countries sharing some homogeneity present some interdependence between them that may affect the results. To adjust for such common factors, we subtract from each series at any time the average of the group. The last transformation, time-demeaning, is performed to control for time fixed effects $\left(\gamma_{t}\right)$. We subtract the mean of each variable calculated for each country-year. To proceed with the panel VAR estimation, stationary data are needed. Hence, the next step is to test whether the main variables of interest are stationary by applying three different panel unit root tests: The Levin, Lin, and Chu test, the Breitung test, and the Im, Pesaran, and Chin test. All are reported in Table 3. With one exception, the results suggest that the three variables of interest are stationary. The exception is the Breitung test for $m_{t}$ in the EU6 panel. ${ }^{10}$

At this point, it should be mentioned that the presence of structural breaks in panel series data can induce behavior similar to that of an integrated process, making it difficult to differentiate between a unit root and a stationary process with a regime shift. For this reason, the panel unit root tests used here may potentially suffer from a significant loss of power if structural breaks are present in the data. In view of this, it was decided to employ the panel data unit root test based on the Lagrangian multiplier (LM) principle developed by Im and Lee. It is very flexible since it can be applied not only when a structural break occurs at a different time period in each time series, but also when the structural break occurs in only some of the time series. The proposed test is not only robust to the presence of structural breaks but also is more powerful than the popular IPS test in the basic scenario where no structural breaks are involved. Furthermore, as reported by Im and Lee, since the LM test loses little power by controlling for spurious structural breaks when they do not exist, this represents a reasonable strategy to control for breaks even when they are only at a suspicious level. Moreover, this panel LM test does not require the simulation of new critical values that depend on the number and location of breaks. The results of this testing procedure as well a more detailed discussion of the findings is 
Table 4: Panel cointegration test results

$\begin{array}{lc}\text { Model } & A D F \\ \text { without deterministic component } & -1.994 \\ \text { with intercept } & -1.328 \\ \text { with trend } & -0.705\end{array}$

Note: As the tests are one-sided, a calculated statistic smaller than the critical value leads to the rejection of the null hypothesis of no cointegration.

Table 5: Results for the three-variable PVAR model

\begin{tabular}{|c|c|c|c|}
\hline \multicolumn{2}{|c|}{$\operatorname{inv}(t-1)$} & $g d p(t-1)$ & \multirow[t]{2}{*}{ milex $(t-1$} \\
\hline & \multicolumn{2}{|c|}{$E U 15(o b s=765)$} & \\
\hline $\operatorname{inv}(t)$ & $\begin{array}{c}0.109 \\
(0.024)\end{array}$ & $\begin{array}{c}0.105 \\
(\mathbf{0 . 0 0 0})\end{array}$ & $\begin{array}{c}-0.568 \\
(0.138)\end{array}$ \\
\hline$g d p(t)$ & $\begin{array}{c}-0.381 \\
(\mathbf{0 . 0 0 0})\end{array}$ & $\begin{array}{c}-0.246 \\
(0.000)\end{array}$ & $\begin{array}{c}1.233 \\
(0.926)\end{array}$ \\
\hline $\operatorname{milex}(t)$ & $\begin{array}{l}-0.007 \\
(0.421)\end{array}$ & $\begin{array}{l}-0.005 \\
(0.102)\end{array}$ & $\begin{array}{c}0.004 \\
(0.967)\end{array}$ \\
\hline & \multicolumn{3}{|c|}{$E U 6(o b s=306)$} \\
\hline $\operatorname{inv}(t)$ & $\begin{array}{c}0.275 \\
(0.000)\end{array}$ & $\begin{array}{c}0.133 \\
(\mathbf{0 . 0 0 0})\end{array}$ & $\begin{array}{r}-0.185 \\
(0.613)\end{array}$ \\
\hline$g d p(t)$ & $\begin{array}{l}-0.666 \\
(\mathbf{0 . 0 0 0})\end{array}$ & $\begin{array}{l}-0.155 \\
(0.026)\end{array}$ & $\begin{array}{c}2.067 \\
(0.026)\end{array}$ \\
\hline milex $(t)$ & $\begin{array}{c}-0.004 \\
(0.6710)\end{array}$ & $\begin{array}{l}-0.009 \\
(\mathbf{0 . 0 0 4})\end{array}$ & $\begin{array}{c}0.126 \\
(0.114)\end{array}$ \\
\hline
\end{tabular}

Notes: p-values in parenthesis. The values in bold-type font are discussed in the text.

presented in the Appendix. Overall, the findings using panel data unit root tests that allow for structural breaks are in support of the already reported results of panel data unit root tests for the GDP growth rates, leading us to conclude that the series is integrated of order zero while the investment and the military expenditure series are integrated of order one. ${ }^{11}$

Having confirmed the nonstationarity of our investment and military expenditure series for the EU15 it is natural to test for the existence of a structural long-run relation between these series. To this effect, we compute Pedroni's cointegration test statistics using conventional (asymptotic) critical values (see Table 4). We present the results for the entire sample of the EU15. Using conventional asymptotic critical values $(-1.66$ at 5 percent), calculated under the assumption of cross-sectional

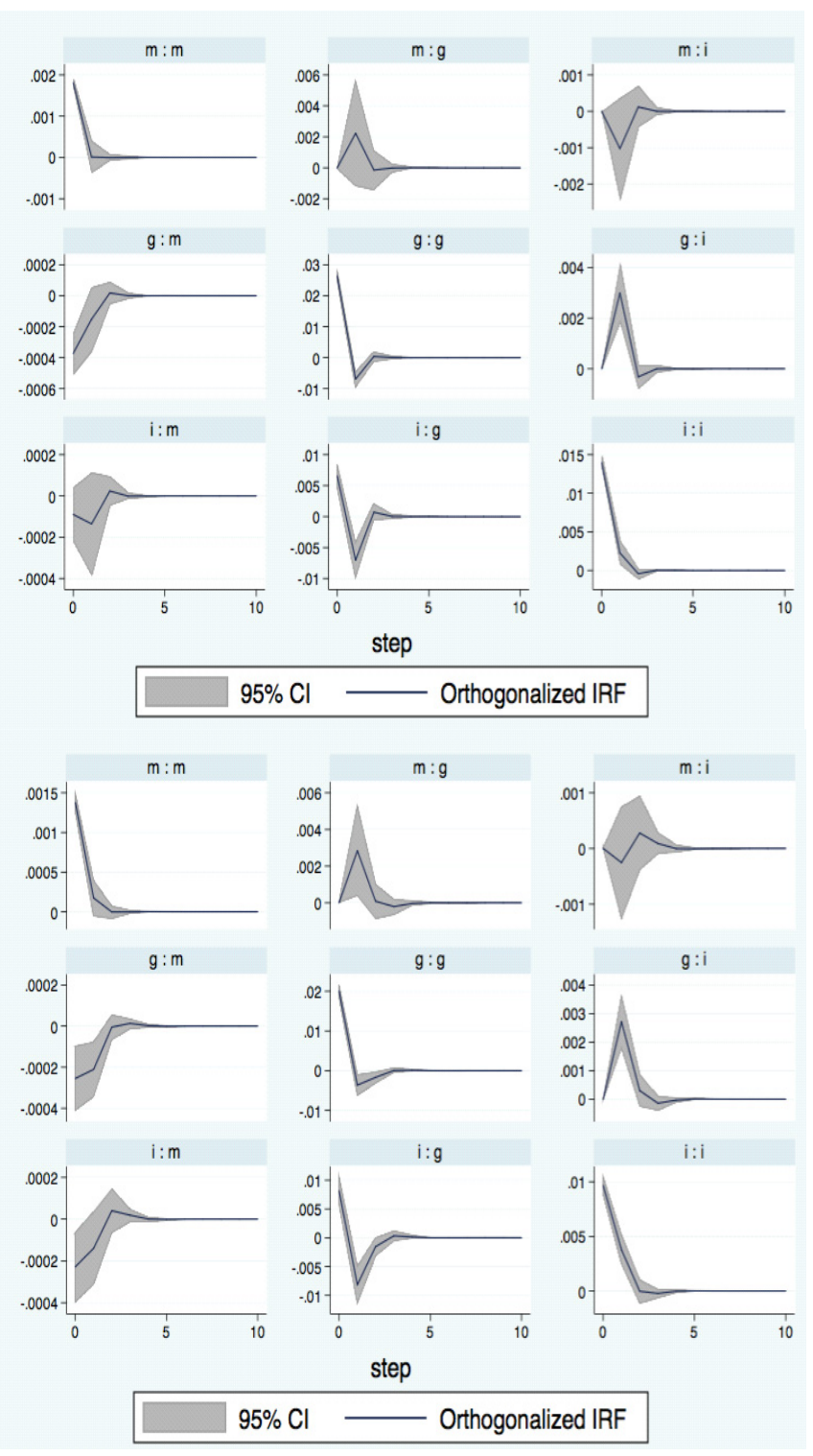

Figure 2: Impulse responses for 1-lag VAR. Top panel: EU15. Bottom panel: EU6. Note: Based on the three model selection criteria by Andrews and $\mathrm{Lu}$ (2001) and the overall coefficient of determination, the first-order panel VAR is the preferred model since this has the smallest MBIC, MAIC, and MQIC.

independence (reported in Pedroni, 1999, and extracted from the standard normal distribution), the null hypothesis of no cointegration between investment and military expenditure is accepted by the test statistics only when the model has no deterministic component. ${ }^{12}$

The results from estimating the PVAR for the entire sample as well as the subsample are presented in Table 5. Broadly, no significant differences between the EU15 and the EU6 samples emerge. Focusing on military expenditure (column 3 in Table 5), no statistically traceable and significant impact is detected 
either on the growth rates or on investment, although the respective signs could hint at effective demand stimulation and crowding-out effects which, however, are not statistically significant and hence cannot support any inference in this regard. The only noteworthy difference between the two samples is the effect that economic growth seems to exert on the defense burden in the case of the EU6 sample (column 2).

As the next step in the analysis, and prior to estimating impulse response functions (IRFs), we check the stability condition of the two estimated panel VARs. The results for the EU15 and for the EU6 subsample are shown in Figure A1 in the Appendix. The resulting graph of the eigenvalues confirm that the estimates have stationary roots since all eigenvalues lie inside the unit circle. The estimated IRFs for both samples, then, are shown in Figures 2 and include their confidence intervals represented by the lower and upper lines on the graphs. The middle lines are the actual response functions, depicting the dynamics of the response of the one variable to shocks of the other variables in the panel. Once again focusing on the effects of a shock in military expenditure, it would appear that they are short-lived. The short-run dynamics depicted by the IRFs suggest that a shock in the military spending variable brings about an increase in growth and a decrease in investment, pointing on the one hand to stimulative effects — probably via the effective demand channel—and, on the other hand, a crowding-out impact as suggested in the relevant literature.

\section{Conclusion}

The availability of longer and consistent time series on military expenditure presents the opportunity to reassess their effects on the economy. This study focused on the EU15 over the period 1961-2014 as well as on a subsample of six countries which house a comparatively sizeable defense industrial base. Based on the results of the PVAR method employed herein, it would appear that military expenditure does not exert any statistically significant and traceable effect on the economy. Hence, the effective demand stimulation argument is not supported, neither for the whole sample (the EU15) nor for the subsample (the EU6) where any such an effect, if it exists, should be more evident.

\section{Notes}

The helpful comments and constructive suggestions by two anonymous referees and valuable editorial guidance by Jurgen Brauer are gratefully acknowledged. The usual disclaimer applies.
1. Literature surveys: Dunne and Uye (2010); Dunne and Tian (2013). Multiple channels: See, e.g., Heo and Ye (2016); Dunne, Smith, and Willenbockel (2005); Drèze (2006); Dunne and Tian (2015). No robust findings: See, e.g., Alptekin and Levine (2012); Dunne and Tian (2013).

2. New SIPRI data: For an initial assessment, see Sandler and George (2016). EU15 literature: See, e.g., Kollias, Mylonidis, and Paleologou (2007); Mylonidis (2008); Kollias and Paleologou (2010); Dunne and Nikolaidou (2012); Chang, Lee, and Chu (2015).

3. Nikolaidou (2008).

4. Six countries: Hartley (2006, 2008).

5. Consistent with the literature: Murdoch, Pi, and Sandler (1997).

6. The first paper that used PVAR in Stata was Love and Zicchino (2006) who, informally, made the program routines available to other researchers. We use the STATA pvar routines by Abrigo and Love (2016) which give an updated package of programs with additional functionality, including subroutines to implement Granger (1969) causality tests and optimal moment and model selection following Andrews and Lu (2001). Sim's traditional VAR: Sims (1980).

7. In line with prior literature: See, e.g,. Dakurah, Davies, and Sampath (2001); Chen, Lee, and Chiu (2014); Chang, Lee, and Chu (2015); Dunne and Nikolaidou (2012).

8. Choleski decomposition: See Hamilton (1994) for a discussion on IRFs and derivations.

9. Fixed effects are correlated: Arellano and Bond (1991); Blundell and Bond (1998). Forward mean-differencing: Arellano and Bover (1995). Using lags as instruments: The coefficients are estimated by GMM, which, in our case, is "just identified," i.e., the number of regressors equals the number of instruments. Hence, it is equivalent to $2 \mathrm{SLS}$.

10. Autocorrelation related to common factors: Levin, Lin, and Chu (2002). Panel unit root tests: Levin, Lin, and Chu (2002); Breitung (2001); Im, Pesaran, and Chin (2003).

11. LM panel unit root test: Im and Lee (2005). IPS test: Im, Pesaran, and Shin (2003).

\section{Pedroni: Pedroni (1999; 2004).}

\section{References}

Abrigo, M.R.M and I. Love. 2016. "Estimation of Panel Vector Autoregression in Stata: a Package of Programs." University of Hawaii. Working paper No. 16-2. http://www.economics.hawaii.edu/research/workingpape rs/WP_16-02.pdf.

Alptekin, $\bar{A}$. and P. Levine. 2012. "Military Expenditure and Economic Growth: A Meta-Analysis.” European Journal of Political Economy. Vol. 28, No. 4, pp. 636-650. http://dx.doi.org/10.1016/j.ejpoleco.2012.07.002

Andrews, D.W.K. and B. Lu. 2001. "Consistent Model and Moment Selection Procedures for GMM Estimation with Application to Dynamic Panel Data Models." Journal of

The Economics of Peace and Security Journal — ISSN 1749-852X — http://www.epsjournal.org.uk (C) EPS Publishing, 2016. All rights reserved. For permissions, email: ManagingEditor@epsjournal.org.uk 
Econometrics. Vol. 101, No. 1, pp. 123-164. http://dx.doi.org/10.1016/S0304-4076(00)00077-4

Arellano, M. and S. Bond. 1991. "Some Tests of Specification for Panel Data: Monte Carlo Evidence and an Application to Employment Equations." Review of Economic Studies. Vol. 58, No. 2, pp. 277-297. http://dx.doi.org/10.2307/2297968

Arellano, M. and O. Bover. 1995. "Another Look at the Instrumental Variable Estimation of Error Components Model." Journal of Econometrics. Vol. 68, No. 1, pp. $29-51$ http://dx.doi.org/10.1016/0304-4076(94)01642-D

Blundell, R. and S. Bond. 1998. "Initial Conditions and Moment Restrictions in Dynamic Panel Data Models." Journal of Econometrics. Vol. 87, No. 1, pp. 115-143. http://dx.doi.org/10.1016/S0304-4076(98)00009-8

Breitung, J. 2001. "The Local Power of Some Unit Root Tests for Panel Data," pp. 161-177 in B.H. Baltagi, T.B. Fomby, and R. Carter Hill, eds. Nonstationary Panels, Panel Cointegration, and Dynamic Panels. Bingley, UK: Emerald.

Canova, F. and M. Ciccarelli. 2004. "Forecasting and Turning Point Predictions in a Bayesian Panel VAR model." Journal of Econometrics. Vol. 120, No. 2, pp. 327-359. http://dx.doi.org/10.1016/S0304-4076(03)00216-1

Chang, T., C-C. Lee, and H-P. Chu. 2015. "Revisiting the Defense-Growth Nexus in European Countries." Defence and Peace Economics. Vol. 26, No. 3, pp. 341-356. http://dx.doi.org/10.1080/10242694.2013.832556

Chen, P.F., C.C. Lee, and Y.B. Chiu. 2014. "The Nexus between Defense Expenditure and Economic Growth: New Global Evidence.” Economic Modelling. Vol. 36 (January), pp. 474-483.

http://dx.doi.org/10.1016/j.econmod.2013.10.019

Dakurah, H., S. Davies, and R. Sampath. 2001. "Defense Spending and Economic Growth in Developing Countries: A Causality Analysis." Journal of Policy Modeling. Vol. 23, No. 6, pp. 651-658.

http://dx.doi.org/10.1016/S0161-8938(01)00079-5

Drèze, J. 2006. "Military Expenditure and Economic Growth," pp. 377-381 in D.E. Clark, ed. The Elgar Companion to Development Studies. Cheltenham, UK: Elgar.

Dunne, J.P., R.P. Smith, and D. Willenbockel. 2005. "Models of Military Expenditure and Growth: A Critical Review." Defence and Peace Economics. Vol. 16, No. 6, pp. 449-461. http://dx.doi.org/10.1080/10242690500167791

Dunne, J.P. and N. Tian. 2013. "Military Expenditure and Economic Growth: A Survey." Economics of Peace and Security Journal. Vol. 8, No. 1, pp. 5-11. http://dx.doi.org/10.15355/epsj.8.1.5

Dunne, J.P. and N. Tian. 2015. "Military Expenditure, Economic Growth and Heterogeneity." Defence and Peace Economics. Vol. 26, No. 1, pp. 15-31. http://dx.doi.org/10.1080/10242694.2013.848575

Dunne, J.P. and E. Nikolaidou. 2012. "Defence Spending and
Economic Growth in the EU15." Defence and Peace Economics. Vol. 23, No. 6, pp. 537-548. http://dx.doi.org/10.1080/10242694.2012.663575

Dunne, J.P. and M. Uye. 2010. "Military Spending and Development," pp. 293-305 in A. Tian, ed. The Global Arms Trade: A Handbook. London: Routledge.

Hartley, K. 2006. "Defense Industrial Policy in a Military Alliance." Journal of Peace Research. Vol. 43, No. 4, pp. 473-489. http://dx.doi.org/10.1177/0022343306064976

Hartley, K. 2008. "Collaboration and European Defence Industrial Policy." Defence and Peace Economics. Vol. 19, No. 4, pp. 303-315. http://dx.doi.org/10.1080/10242690802221585

Heo, U. and M. Ye. 2016. "Defense Spending and Economic Growth around the Globe: The Direct and Indirect Link." International Interactions. Vol. 42, No. 5, pp. 774-796. http://dx.doi.org/10.1080/03050629.2016.1149067

Im, K., M. Pesaran, and Y. Shin. 2003. "Testing for Unit Roots in Heterogeneous Panels." Journal of Econometrics. Vol. 115 , No. 1, pp. 53-74. http://dx.doi.org/10.1016/S0304-4076(03)00092-7

Im, K. and J. Lee. 2005. "Panel LM Unit Root Test with Level Shifts." Oxford Bulletin of Economics and Statistics. Vol. 67, No. 3, pp. 393-419. http://dx.doi.org/10.1111/j.1468-0084.2005.00125.x

Kollias, C. and S.-M. Paleologou. 2010. "Growth, Investment and Military Expenditure in the European Union 15." Journal of Economic Studies. Vol. 37, No. 2, pp. 228-240. http://dx.doi.org/10.1108/01443581011043618

Kollias, C., N. Mylonidis, and S.-M. Paleologou. 2007. "A Panel Data Analysis of the Nexus between Defence Spending and Growth in the European Union." Defence and Peace Economics. Vol. 18, No. 1, pp. 75-85. http://dx.doi.org/10.1080/10242690600722636

Lee, J. and M. Strazicich. 2003. "Minimum Lagrange Multiplier Unit Root Test with Two Structural Breaks." Review of Economics and Statistics. Vol. 85, No. 4, pp. 1082-1089. http://dx.doi.org/10.1162/003465303772815961

Levin, A., C.-F. Lin, and C.-S. J. Chu. 2002. "Unit Root Tests in Panel Data: Asymptotic and Finite-Sample Properties." Journal of Econometrics. Vol. 108, No. 1, pp. 1-24. http://dx.doi.org/10.1016/S0304-4076(01)00098-7

Love, I. and L. Zicchino. 2006. "Financial Development and Dynamic Investment Behavior: Evidence from Panel VAR." Quarterly Review of Economics and Finance. Vol. 46, No. 2, pp. 190-210. http://dx.doi.org/10.1016/j.qref.2005.11.007

Murdoch, J., C.-R. Pi, and T. Sandler. 1997. "The Impact of Defence and Non-Defence Public Spending on Growth in Asia and Latin America." Defence and Peace Economics. Vol. 8, No. 2, pp. 205-224. http://dx.doi.org/10.1080/10430719708404876

Mylonidis, N. 2008. "Revisiting the Nexus between Military Spending and Growth in the European Union." Defence

The Economics of Peace and Security Journal — ISSN 1749-852X — http://www.epsjournal.org.uk

(c) EPS Publishing, 2016. All rights reserved. For permissions, email: ManagingEditor@epsjournal.org.uk 
and Peace Economics. Vol. 19, No. 4, pp. 265-272. http://dx.doi.org/10.1080/10242690802164801

Nikolaidou, E. 2008. "The Demand for Military Expenditure: Evidence from the EU15." Defence and Peace Economics. Vol. 19, No. 4, pp. 273-292. http://dx.doi.org/10.1080/10242690802166533

Pedroni, P. 1999. "Critical Values for Cointegrating Tests in Heterogeneous Panels with Multiple Regressors." Oxford Bulletin of Economics and Statistics. Vol. 61, No. 1, pp. 653-670.

http://dx.doi.org/10.1111/1468-0084.61.s1.14

Pedroni, P. 2004. "Panel Cointegration; Asymptotic and Finite Sample Properties of Pooled Time Series Tests with an Application to the Purchasing Power Parity Hypothesis." Econometric Theory. Vol. 20, No. 3, pp. 597-625. http://dx.doi.org/10.1017/S0266466604203073

Sandler, T. and J. George. 2016. "Military Expenditure Trends for 1960-2014 and What they Reveal." Global Policy. Vol. 7, No. 2, pp. 174-184. http://dx.doi.org/10.1111/1758-5899.12328

Schmidt, P. and P. Phillips. 1992. "LM Tests for a Unit Root in the Presence of Deterministic Trends." Oxford Bulletin of Economics and Statistics. Vol. 54, No. 3, pp. 257-287. http://dx.doi.org/10.1111/j.1468-0084.1992.tb00002.x

Sims, C.A. 1980. "Macroeconomics and Reality." Econometrica. Vol. 48, No. 1, pp. 1-48. http://dx.doi.org/10.2307/1912017

Zivot, E. and D. Andrews. 1992. "Further Evidence of the Great Crash, the Oil-Price Shock and the Unit-Root Hypothesis." Journal of Business and Economic Statistics. Vol. 10, No. 3, pp. 251-270.

Appendix: Panel unit root tests allowing for structural breaks

To provide for additional robustness, we compare both univariate and panel LM unit root test results with and without structural break. We begin with the Schmidt and Phillips (1992) univariate LM unit root test, without any structural change. We then move to extensions that allow for one break since our time series covers periods during which structural change may have occurred due to structural and institutional changes in the EU15 countries. In addition to the Schmidt and Phillips (1992) no-break test, we employ the univariate test and the Lee and Strazicich (2003) minimum LM unit root tests with one break to determine the structural break point in each country. After determining the optimal break point, we employ the panel LM unit root test of Im and Lee (2005). For comparison, we also show the panel LM test results without breaks.

To determine the optimal break point in the panel LM test, we utilize the univariate minimum LM unit root tests of Lee and Strazicich (2003). These tests are comparable to the corresponding Dickey and Fuller-type endogenous break tests of Zivot and Andrews (1992). The performance of the LM test is comparable to or superior to these counterpart tests in terms of size and power. In addition, the LM unit root tests are not subject to spurious rejections under the null. In each test, the break point is determined endogenously from the data via a grid search by selecting the break where the value of the unit root test statistic is at its minimum. Using the minimum LM tests of Lee and Strazicich (2003), the unit root test statistic is estimated at each break point.

The results are reported in Tables A1, A2 and A3, which, respectively, show the results for GDP growth rates and investment and military expenditure as a percentage of GDP. For the univariate LM test without break, the unit root null can be rejected at the 5 percent level of significance in five countries for the GDP growth rates (France, Greece, Ireland, Netherlands, and Spain), in fourteen countries for investment (the exception is Luxemburg), and in fourteen countries for military expenditure (all except France). After allowing for a structural break, the univariate minimum LM test rejects the unit root null in all countries for the GDP growth rates, in twelve countries (except Luxemburg, Sweden, and the U.K.) for Investment and nine countries (Austria, Denmark, Finland, Germany, Greece, Netherlands, Portugal, Spain, and Sweden) for military expenditure at the 5 percent level. Without allowing for structural breaks, the panel LM test statistic is -6.953 for the GDP growth rates, clearly indicating that the unit root null can be rejected at the 5 percent level of significance due to increased power from panel data. In addition, after allowing for structural breaks, the panel test statistic of -7.124 also strongly rejects the unit root null at the 5 percent level.

Concerning investment and the military expenditure series taken as a percentage of GDP, it appears that the panel LM test statistics, with or without a break, cannot reject the null unit root hypothesis at the 5 percent level of significance, thus providing strong evidence in favor of a unit root in these two EU15 country series. 
Table A1: Panel LM unit root tests allowing for structural break for GDP growth rates

$\begin{array}{lccccc}\text { Country } & (1) & (2) & (3) & \text { (4) } & \text { (5) } \\ \text { Austria } & -3.514^{*} & 1 & -6.818^{*} & 1 & 1982 \\ \text { Belgium } & -5.272^{*} & 1 & -7.428^{*} & 1 & 1982 \\ \text { Denmark } & -4.419^{*} & 1 & -6.931^{*} & 1 & 1975 \\ \text { Finland } & -4.582^{*} & 1 & -5.481^{*} & 1 & 2006 \\ \text { France } & -2.825 & 1 & -5.937^{*} & 0 & 1981 \\ \text { Germany } & -5.158^{*} & 2 & -6.917^{*} & 1 & 1982 \\ \text { Greece } & -2.475 & 1 & -5.050^{*} & 0 & 2005 \\ \text { Ireland } & -2.593 & 2 & -4.268^{*} & 0 & 2000 \\ \text { Italy } & -3.220^{*} & 1 & -6.658^{*} & 1 & 2006 \\ \text { Luxembourg } & -4.853^{*} & 1 & -6.243^{*} & 0 & 2000 \\ \text { Netherlands } & -3.040 & 1 & -6.003^{*} & 1 & 1978 \\ \text { Portugal } & -3.215^{*} & 1 & -5.756^{*} & 0 & 2000 \\ \text { Spain } & -3.042 & 1 & -3.929^{*} & 0 & 1976 \\ \text { Sweden } & -4.934^{*} & 1 & -5.866^{*} & 0 & 1978 \\ \text { U.K. } & -4.263^{*} & 2 & -5.702^{*} & 1 & 2001 \\ \text { Panel LM stat } & -6.953^{*} & & -7.124^{*} & \end{array}$

Notes: Column (1) Individual LM statistic without break; (2) lags; (3) individual LM statistic with break; (4) lags; (5) optimal break point. Other notes are at the end of Table A3.

Table A2: Panel LM unit root tests allowing for structural break for GDP investment (as percent of GDP)

$\begin{array}{lccccc}\text { Country } & \text { (1) } & \text { (2) } & \text { (3) } & \text { (4) } & \text { (5) } \\ \text { Austria } & -1.071 & 1 & -3.363 & 0 & 1999 \\ \text { Belgium } & -1.993 & 1 & -3.435 & 1 & 1985 \\ \text { Denmark } & -2.212 & 1 & -3.261 & 1 & 1982 \\ \text { Finland } & -2.240 & 1 & -3.969 & 1 & 1975 \\ \text { France } & -1.421 & 0 & -3.554 & 0 & 1996 \\ \text { Germany } & -2.719 & 2 & -3.545 & 1 & 1976 \\ \text { Greece } & -1.322 & 1 & -2.931 & 0 & 2006 \\ \text { Ireland } & -3.167 & 2 & -3.162 & 2 & 1970 \\ \text { Italy } & -1.739 & 1 & -2.812 & 2 & 1975 \\ \text { Luxembourg } & -3.709 * & 1 & -4.902 * & 2 & 1970 \\ \text { Netherlands } & -0.912 & 1 & -2.963 & 0 & 1977 \\ \text { Portugal } & -0.713 & 1 & -3.437 & 0 & 1980 \\ \text { Spain } & -2.945 & 2 & -3.109 & 1 & 2006 \\ \text { Sweden } & -1.987 & 1 & -3.816^{*} & 1 & 1997 \\ \text { U.K. } & -1.669 & 2 & -3.755^{*} & 1 & 1989 \\ \text { Panel LM stat } & -2.895 & & & & \end{array}$

Notes: Column (1) Individual LM statistic without break; (2) lags; (3) individual LM statistic with break; (4) lags; (5) optimal break point. Other notes are at the end of Table A3.
Table A3: Panel LM unit root tests allowing for structural break for GDP military expenditure (as percent of GDP)

$\begin{array}{lccccc}\text { Country } & \text { (1) } & \text { (2) } & \text { (3) } & \text { (4) } & \text { (5) } \\ \text { Austria } & -0.781 & 1 & -3.793^{*} & 1 & 1984 \\ \text { Belgium } & -0.184 & 1 & -2.103 & 1 & 1976 \\ \text { Denmark } & -0.609 & 1 & -3.844^{*} & 1 & 1971 \\ \text { Finland } & -2.333 & 1 & -3.746^{*} & 1 & 1969 \\ \text { France } & -3.079 & 1 & -3.169 & 0 & 2006 \\ \text { Germany } & -1.709 & 2 & -4.275^{*} & 1 & 1969 \\ \text { Greece } & -1.270 & 1 & -4.365^{*} & 0 & 1977 \\ \text { Ireland } & -0.327 & 1 & -3.429 & 1 & 1976 \\ \text { Italy } & -1.071 & 1 & -3.459 & 0 & 1975 \\ \text { Luxembourg } & -1.221 & 1 & -2.803 & 0 & 1970 \\ \text { Netherlands } & -1.651 & 1 & -3.870^{*} & 0 & 1969 \\ \text { Portugal } & -1.263 & 1 & -5.768^{*} & 0 & 1983 \\ \text { Spain } & -0.497 & 2 & -4.209^{*} & 2 & 1984 \\ \text { Sweden } & -0.152 & 2 & -3.582^{*} & 0 & 1991 \\ \text { U.K. } & -1.325 & 2 & -2.632 & 2 & 2005 \\ & & & & & \\ \text { Panel LM stat } & 0.727 & & -1.039 & & \\ & & & & & \end{array}$

Notes: Column (1) Individual LM statistic without break; (2) lags; (3) individual LM statistic with break; (4) lags; (5) optimal break point.

(1) All tests are one-sided so that a calculated statistic smaller than the critical value leads to the rejection of the null of a unit root. At 5 percent, the critical value for the LM test without break is -3.06 . At 5 percent the critical value for the minimum LM test with one break is -3.566 . (2) The critical value for the panel LM test (with or without breaks) is -1.645 , with an asymptotic standard normal distribution. (3)* denotes significance at the 5 percent level. (a) Schmidt and Phillips (1992) test; (b) Lee and Strazicich (2003) test; (c) Im and Lee (2005) test.
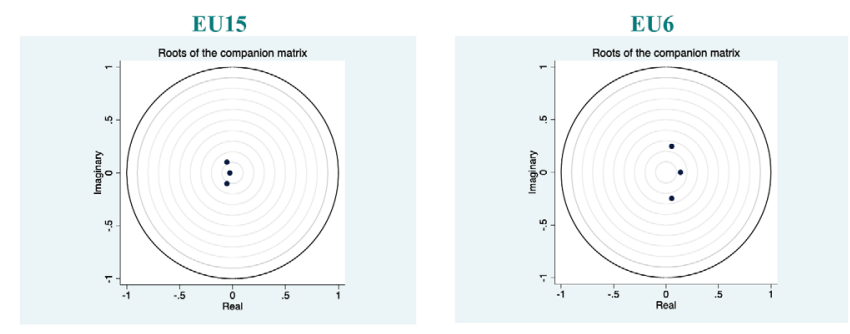

Figure A1: Stability tests. 